\title{
Pengaruh Pemberian Ekstrak Air Buah Pepaya Muda (Carica papaya.L) terhadap Gambaran Histologi Ovarium Tikus Betina (Rattus norvegicus)
}

\author{
Okti Satria ${ }^{1}$, Yanwirasti ${ }^{2}$, Arni Amir ${ }^{3}$ \\ ${ }^{1}$ Ilmu Kebidanan, Fakultas Kedokteran, Universitas Andalas, Padang \\ ${ }^{2}$ Anatomi, Fakultas Kedokteran, Universitas Andalas, Padang \\ ${ }^{3}$ Biologi, Fakultas Kedokteran, Universitas Andalas, Padang \\ Email: user.chiot@gmail.com
}

\begin{abstract}
Papaya seed (Carica papaya L.) as antifertility has been known since 1970 can cause the quantity and quality of sperm decreased. This antifertility potency is reinforced by the existence of research showing that inside papaya seeds contain antifertility compound that is saponin. In young papaya fruit (Carica papaya L.) also contains saponins, alkaloids, minerals, vitamins, and enzymes. The latex sap from the young papaya fruit has the same influence as oxytocin on the uterus of both pregnant and non-pregnant rats (Gouado et al., 2007) this study was conducted to prove that in the water extract of young papaya fruit has antifertility effect. If this study is meaningful, it may be used as a reference for subsequent research on efforts to utilize bio-natural resources as a medicinal substance. The purpose of this study is to know the influence of young papaya fruit extract on overview of ovarium histology of female rat. This research is a quantitative research using post-test design only control group design. This research is experimental with design. The research has been conducted from November to December 2017. This research was conducted at the Regional Center of Veterinary Investigation and Testing (RSVIT) II of Bukittinggi. The population in this study was female rats with a total number of female rats during the study of 32 rats. The results showed that Fresh Papaya Fruit Extract significantly influenced the number of primary follicles and follicles of rat Atresia (Rattus novergicus) $(p=0,000)$. Young Pepaya Fruit Water Extract can be considered as an efficient natural contraceptive and a few side effects.
\end{abstract}

\section{Keyword : Papaya Fruit Water Extract, Ovarian Histology of Female Rat}

\section{PENDAHULUAN}

Penggunaan alat kontrasepsi di Indonesia masih kurang. Berdasarkan data Survei Demografi Kesehatan Indonesia (SDKI) tahun 2012 penggunaan non Metode Kontrasepsi Jangka Panjang (MKJP) meningkat dari 46,5 \% menjadi 47,3\%, sementara penggunaan Metode Kontrasepsi Jangka Panjang (MKJP) menurun dari 10,9 menjadi 10,6\% (Badan Pusat Statistik et al., 2013). Badan Kependudukan dan Keluarga Berencana Nasional (BKKBN) tahun 2016 melaporkan bahwa pemakaian alat kontrasepsi di Sumatera Barat secara total adalah sebanyak 129.899 peserta atau 84,85 \% dari perkiraan permintaan masyarakat sebesar 107,125 peserta. Kontrasepsi merupakan upaya untuk mencegah terjadinya kehamilan. Upaya itu dapat bersifat sementara, dapat pula bersifat permanen. Baru-baru ini, upaya telah dikhususkan untuk mengidentifikasi tanaman berbasis formulasi kontrasepsi yang seharusnya secara lisan bioaktif, tidak beracun dan lebih efektif berdasarkan biaya pada ethano informasi medis (Zade and Dabhadkar, 2015)
Berbagai jenis tumbuhan dapat digunakan sebagai obat tradisional, salah satu tumbuhan yang penting untuk diteliti adalah tanaman pepaya (Carica papaya L). Kandungan kimia yang terdapat pada pepaya mengandung spektrum yang luas dari phytochemical termasuk, polisakarida, vitamin, mineral, enzim, protein, alkaloid, glikosida, lemak dan minyak, lektin, saponin, flavonoid, sterol, dan lain-lain (Krishna, Paridhavi and Patel, 2008)

Biji pepaya (Carica pepaya) sebagai antifertilitas sudah diketahui sejak tahun 1970 dapat menyebabkan kuantitas dan kualitas sperma menurun. Potensi antifertilitas ini diperkuat oleh adanya penelitian yang menunjukkan bahwa didalam biji pepaya terkandung senyawa antifertilitas yaitu saponin. Dalam buah pepaya muda (Carica papaya $L$.) juga mengandung saponin, alkaloid, mineral, vitamin, dan enzim. Getah (lateks) dari buah pepaya muda memiliki efek yang sama dengan oksitosin pada uterus tikus hamil maupun tidak hamil (Gouado et al., 2007)

Bahan aktif pepaya yaitu triterpenoid saponin, alkaloid dan flavanoid yang merupakan 
salah satu turunan steroid, bahan aktif steroid dan triterpenoid diduga sebagai bahan aktif yang bekerja sebagai faktor antifertilitas. Kedua bahan aktif tersebut diduga mampu mengakibatkan gangguan pada jalur hipotalamus hipofise yang selanjutnya mengakibatkan gangguan sekresi GnRH yang kemudian akan berpengaruh terhadap pembentukan, perkembangan dan pematangan folikel (Plants, Dhamija and Aurangabad, 2015)

Bahan antifertilitas yang bekerja pada poros hipothalamus-hipofise-ovarium mempunyai aktifitas gonadotropin, dengan mekanisme umpan balik negatif dari hipothalamus yang menyebabkan penurunan produksi GnRH. Hal ini akan berpengaruh pada sekresi FSH dan LH dari hipofise anterior, sehingga sekresi FSH dan LH rendah, dimana kedua hormon ini sangat berpengaruh dalam pembentukan, perkembangan dan pematangan folikel ovarium serta proses ovulasi (Gouado et al., 2007)

Senyawa saponin dan flavonoid dapat disintesis menjadi antiestrogen di dalam tubuh. Antiestrogen menyebabkan ovarium inaktif, pertumbuhan folikel dan sekresi estrogenendogen terganggu karena itu ovulasi dapat terganggu. Pengaruh lain dari senyawa ini adalah kelenjar serviks menjadi sedikit dan lebih kental, keadaan ini akan mengganggu motilitas spermatozoa, maka tidak terjadi fertilisasi meskipun terjadi perkawinan. Efek lain antiestrogen menyebabkan atrofi endometrium, sehingga meskipun terjadi fertilisasi proses implantasi akan terganggu (Plants, Dhamija and Aurangabad, 2015)

Saponin mempunyai pengaruh negatif terhadap reproduksi ternak seperti aborsi atau kematian, menyebabkan steril dan penghentian proses kebuntingan. Saponin berperan besar dalam pengeluaran hormon Luteinizing. Saponin steroid secara langsung menghambat kerja gen yang bertanggungjawab dalam proses steroidogenesis dan menekan perkembangan sel granula yang diatur oleh hormon perangsang folikel dalam ovarium (Francis et al., 2002)

Bahan aktif saponin, steroid dan triterpenoid pada pepaya diduga sebagai bahan aktif yang bekerja sebagai faktor antifertilitas. Hal tesebut dikarenakan ketiga bahan aktif tersebut diduga mampu mengakibatkan gangguan jalur hipotalamus hipofise yang selanjutnya mengakibatkan gangguan sekresi GnRH yang kemudian akan berpengaruh terhadap pembentukan, perkembangan dan pematangan folikel (Susantoputro et al., 2014)

Perlu dilakukan penelitian tentang Pengaruh Ekstrak Air Buah Pepaya Muda (Carica papaya L.) terhadap Gambaran Histologi Ovarium Tikus Betina (Rattus norvegicus). Selanjutnya penelitian ini dilakukan untuk membuktikan bahwa didalam ekstrak air buah pepaya muda mempunyai efek antifertilitas. Jika penelitian ini bermakna, kemungkinan dapat digunakan sebagai acuan penelitian berikutnya tentang upaya pendayagunaan sumber daya alam nabati sebagai bahan obat.

\section{METODE PENELITIAN}

Penelitian ini bersifat eksperimental dengan desain the post test only control group design yaitu rancangan yang digunakan untuk melihat pengaruh perlakuan pada kelompok eksperimen yang menggunakan rancangan acak lengkap (RAL) dengan cara membandingkan kelompok perlakuan dengan kelompok kontrol. Subjek penelitian merupakan Tikus betina yang terdapat pada Balai Penyidikan dan Pengujian Veteriner (BPPV) Regional II Bukittinggi. Uji statistik yang digunakan yaitu parametrik One Way ANOVA dengan derajat kepercayaan 95\% dan jika terdapat perbedaan yang bermakna maka dilanjutkan dengan uji statistik Multiple Comparisons (Post Hoc Test) jenis Bonferroni untuk melihat signifikansi antar kelompok.

\section{HASIL DAN PEMBAHASAN}

Untuk mengetahui apakah pemberian Ekstrak Air Buah Pepaya Muda antar kelompok perlakuan memberikan pengaruh maka perlu dilakukan analisis perbandingan masing-masing kelompok perlakuan. Oleh karena itu sebelum melakukan analisis tersebut, data yang diperoleh diuji normalitas terlebih dahulu, uji normalitas yang digunakan adalah uji Shapiro Wilk. Hasil uji normalitas didapat data tidak terdistribusi normal dengan nilai $\mathrm{p}=0,006 \quad(\mathrm{p} \leq 0,05)$, kemudian dilanjutkan dengan uji Kruskal-Wallis. 
Tabel 1. Perbandingan Jumlah Foliker Primer Pada Kelompok Kontrol dan Ekstrak Air Buah Pepaya Muda

\begin{tabular}{cccc}
\hline Kelompok Subjek & n & Rata-rata Jumlah Folikel Primer \pm & p \\
\hline Kontrol Negatif & 6 & $2,50 \pm 0,837$ & \\
Perlakuan 1 & 6 & $1,50 \pm 0,548$ & $0,001^{*}$ \\
Perlakuan 2 & 6 & $0,80 \pm 0,408$ & \\
Perlakuan 3 & 6 & $0,30 \pm 0,516$ & \\
\hline
\end{tabular}

Ket: $*$ = berbeda signifikan

Berdasarkan tabel 1 didapatkan bahwa rata-rata jumlah folikel primer lebih banyak ditemukan pada kelompok kontrol $(2,50)$ dibandingkan dengan kelompok perlakuan Ekstrak Air Buah Pepaya Muda $(0,30)$, oleh karena itu dapat diasumsikan bahwa semakin tinggi dosis pemberian Ekstrak Air Buah Pepaya Muda pada tikus betina semakin berkurang juga jumlah folikel primer yang ditemukan pada struktur histologi ovarium tikus tersebut.

Tabel 2 Uji Multiple Comparison Dunn Jumlah Folikel Primer Pada Kelompok Kontrol dan Ekstrak Air Buah Pepaya Muda

\begin{tabular}{llllll}
\hline No & Kelompok & Kontrol & P1 & P2 & P3 \\
\hline 1 & Kontrol & - & 0,820 & $0,022^{*}$ & $0,001^{*}$ \\
2 & P1 & 0,820 & - & 0,927 & 0,100 \\
3 & P2 & $0,022^{*}$ & 0,927 & - & 1,000 \\
4 & P3 & $0,001^{*}$ & 0,100 & 1,000 & - \\
\hline
\end{tabular}

Ket: $*$ = berbeda signifikan

Berdasarkan tabel 2 diketahui bahwa perbedaan yang signifikan terlihat dengan membandingkan jumlah folikel primer pada kontrol dengan perlakuan ke- $2 \mathrm{p}<0,22$ dan pada kontrol dengan perlakuan ke-3 dengan nilai $\mathrm{p}<0,001$.
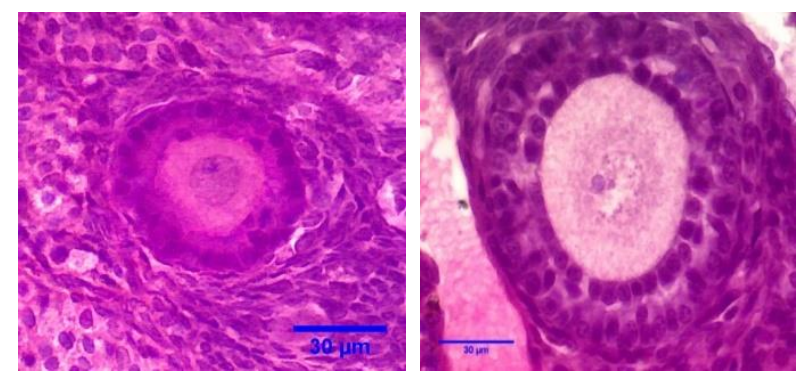

Gambar 1 Folikel Primer, a. Kelompok Kontrol, b. Kelompok P2 (Perbesaran 40X, HE)

Tabel 3 Perbandingan Jumlah Folikel Atresia pada Kelompok Kontrol

\begin{tabular}{llll}
\multicolumn{3}{c}{ dan Ekstrak Air Buah Pepaya Muda } \\
\hline Kelompok Subjek & n & Rata-rata Jumlah Folikel Atresia \pm SD & p \\
\hline Kontrol Negatif & 6 & $15.00 \pm 4,561$ & \\
Perlakuan 1 & 6 & $19,33 \pm 6,439$ & $<0,000^{*}$ \\
Perlakuan 2 & 6 & $27,33 \pm 7,633$ & \\
Perlakuan 3 & 6 & $34,33 \pm 6,501$ & \\
\hline
\end{tabular}

Ket: $*$ = berbeda signifikan

Tabel 3 menunjukkan bahwa rata-rata jumlah folikel yang paling banyak ditemukan yaitu pada kelompok perlakuan P2 dan P3 dengan nilai rata-rata berturut-turut, 27,33 dan 34,33 , sedangkan yang paling rendah ditemukan pada kelompok Kontrol dan P1. 
Tabel 4 Uji Multiple Comparison Bonferroni Jumlah Folikel Atresia pada Kelompok Kontrol dan Ekstrak Air Buah Pepaya Muda

\begin{tabular}{llllll}
\hline No & Kelompok & Kontrol & P1 & P2 & P3 \\
\hline 1 & Kontrol & - & 1,000 & 0,19 & $0,000^{*}$ \\
2 & P1 & 1,000 & - & 0,252 & $0,004^{*}$ \\
3 & P2 & 0,19 & 0,252 & - & 0,431 \\
4 & P3 & $0,000^{*}$ & $0,004^{*}$ & 0,431 & - \\
\hline
\end{tabular}

Ket: $*$ = berbeda signifikan

Uji perbandingan untuk masing-masing kelompok perlakuan berdasarkan tabel 5.4 diketahui bahwa kelompok Kontrol dan P3 berbeda signifikan dengan kelompok P1 dan kelompok P2 untuk jumlah folikel atresia yang ditemukan pada struktur ovarium tikus pada penelitian ini.

Hal ini mengambarkan bahwa pemberian Ekstrak Air Buah Pepaya Muda mempunyai pengaruh terhadap jumlah folikel atresia yang ditemukan pada ovarium tikus pada dosis tinggi.

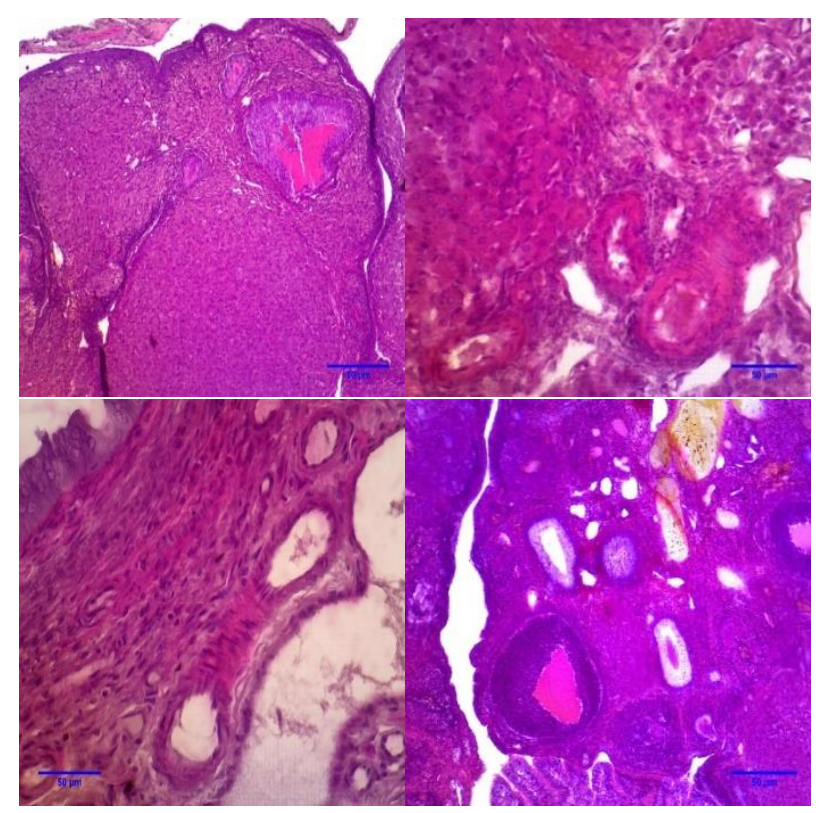

Gambar 2 Tipe Folikel Atresia (FA) (Perbesaran 10X, 40X, HE)

\section{Pembahasan}

Hasil analisis perbandingan jumlah folikel primer dengan uji Kruskal Wallis menujukkan bahwa terdapat perbedaan yang signifikan terhadap jumlah folikel primer antara kelompok kontrol dan perlakuan. Pada uji Multiple Comparasion Dunn dapat dilihat bahwa terdapat perbedaan yang bermakna kelompok perlakuan 2 (93 mg/200 gr BB) dan perlakuan 3 (189 mg/200 gr BB) dengan nilai $\mathrm{p}<0,05$. Hal ini menunjukkan bahwa pada dosis $93 \mathrm{mg} / 200 \mathrm{gr}$ BB sampai $189 \mathrm{mg} / 200$ gr BB ekstrak air buah pepaya muda memberikan pengaruh terhadap jumlah folikel primer sehingga mengganggu proses folikulogenesis pada ovarium.

Folikulogenesis dimulai dari folikel primordial dalam jumlah banyak yang dijumpai pada bagian korteks ovarium. Perekrutan tersebut diatur oleh tekanan jaringan dalam stroma pada korteks ovarium. Kepadatan stroma menurun secara bertahap dari korteks hingga bagian medula (Woodruff and Shea, 2011). Folikulogenesis dimulai saat folikel primordial menuju arah medula yang lebih lunak. Hal tersebut memicu selesainya istirahat meiosis oosit dalam folikel primordial dan berkembang menjadi folikel primer kemudian folikel sekunder (Ramadhani et al., 2017)

Buah pepaya muda (Carica papaya L.) memiliki senyawa yang merupakan golongan saponin, tanin, flavonoid, terpenoid, alkaloid, sterol dan triterpenoid dapat menekan tingkat fertilitas dengan cara mengganggu fungsi ovarium, uterus atau vagina (Sukabumi, 2009). Penurunan jumlah folikel ini diduga karena adanya bahan aktif dari ekstrak air buah pepaya muda yang mengandung saponin, tanin, triterpenoid, alkaloid dan flavanoid yang bersifat sitotoksik.

Berdasarkan hasil uji analisis ANOVA terdapat perbedaan yang signifikan antara kelompok kontrol dengan perlakuan. Setelah dilakukan uji lanjut diketahui bahwa perbedaan tersebut berada pada kelompok perlakuan 2 (93 $\mathrm{mg} / 200 \mathrm{gr} \mathrm{BB})$ dan perlakuan $3(189 \mathrm{mg} / 200 \mathrm{gr}$ $\mathrm{BB})$ dibandingkan dengan kelompok kontrol dan perlakuan 1 (47 mg/200 gr BB). Hasil penelitian ini menunjukkan bahwa semakin tinggi dosis Ekstrak Air Buah Pepaya Muda yang diberikan semakin meningkat jumlah folikel atresia yang ditemukan pada ovarium tikus pada penelitian ini. Folikel atresia yang diamati pada penelitian ini yaitu terdapat pada semua fase perkembangan folikel, seperti atresia pada saat folikel primer, sekunder, de graaf dan korpus luteum. Folikel atresia merupakan folikel yang mengalami perhentian tahapan perkembangan folikel yang dapat terjadi pada semua fase perkembangan folikel. Karakteristik folikel atresia yaitu sel 
granulosa mengalami degenerasi, disorganisasi, berfragmentasi, dan atropi, selain itu sel telur mengalami kehilangan inti sel sehingga menyebabkan kematian sel (District and Nadu, 2015). Folikel atresia atau degenerasi folikel sebelum terjadi ovulasi diduga terjadi akibat berkurangnya atau tidak adanya hormon yang berfungsi untuk pematangan dan differensiasi folikel. Menurut Wassarman dan Albertini hal tersebut dikarenakan penurunan pituitari gonadotropin FSH yang berperan penting dalam pertumbuhan dan perkembangan folikel. Penurunan FSH dapat dikarenakan adanya bahan antifertilitas yang bekerja pada poros hipothalamus-hipofise-ovarium mempunyai aktifitas gonadotropin, dengan mekanisme umpan balik negatif dari hipothalamus yang menyebabkan penurunan produksi GnRH. Hal ini akan berpengaruh pada sekresi FSH dan LH dari hipofise anterior, sehingga sekresi FSH dan LH rendah, dimana kedua hormon ini sangat berpengaruh dalam pembentukan, perkembangan dan pematangan folikel ovarium serta proses ovulasi (Susantoputro et al., 2014)

Hasil uji lanjutan antara keempat kelompok menggunakan uji Multiple Comparison Bonferroni dapat disimpulkan bahwa terdapat penagruh yang signifikan antara jumlah folikel atresia pada kelompok kontrol dengan kelompok perlakuan. Kelompok kontrol dengan perlakuan 1 dan kelompok kontrol dengan perlakuan 3, sedangkan kelompok lain tidak memperlihatkan pengaruh yang signifikan $(\mathrm{p} \geq 0,05)$.

Penelitian ini diketahui terdapat pengaruh yang signifikan pemberian ekstrak air buah pepaya muda terhadap jumlah folikel atresia tikus betina. Nilai rerata jumlah folikel atresia pada kelompok kontrol dengan kelompok perlakuan mengalami peningkatan.

\section{SIMPULAN}

Pemberian Ekstrak Air Buah Pepaya Muda berpengaruh secara signifikan terhadap jumlah folikel primer tikus (Rattus novergicus). Dimana folikel primer pada kelompok perlakuan mengalami penurunan dari kelompok kontrol. Pemberian Ekstrak Air Buah Pepaya Muda berpengaruh secara signifikan terhadap jumlah folikel Atresia tikus (Rattus novergicus). Nilai rerata jumlah folikel Atresia pada kelompok perlakuan mengalami peningkatan dari kelompok kontrol

\section{DAFTAR PUSTAKA}

Badan Pusat Statistik et al. (2013) 'Survei Demografi dan Kesehatan Indonesia 2012', Sdki, p. 16. doi: 10.1111/j.14710528.2007.01580.x.

District, T. and Nadu, T. (2015) 'Effect of Seeded and Seedless Carica Papaya Fruit Extracts on the'.

Francis, G. et al. (2002) 'The biological action of saponins in animal systems: a review', British Journal of Nutrition, 88(06), p. 587. doi: 10.1079/BJN2002725.

Gouado, I. et al. (2007) 'Systemic levels of carotenoids from mangoes and papaya consumed in three forms (juice, fresh and dry slice)', European Journal of Clinical Nutrition, 61(10), pp. 1180-1188. doi: 10.1038/sj.ejcn.1602841.

Krishna, K. L., Paridhavi, M. and Patel, J. A. (2008) 'Review on nutritional, medicinal and pharmacological properties of papaya (Carica papaya linn.)', Indian Journal of Natural Products and Resources, 7(4), pp. 364-373. doi: 0975-6299.

Plants, H. M., Dhamija, I. and Aurangabad, S. (2015) 'Antifertility Activity of Medicinal Plants on Male and Female', Intrmational Journal Pharmacutical, 6(3), p. 13040. doi: 10.13040/IJPSR.0975-8232.6(3).98801.

Ramadhani, S. A. et al. (2017) 'Pengendalian Folikulogenesis Ovarium dengan Pemberian Ekstrak Biji Kapas Folliculogenesis Control in Ovarian with the Cottonseed Extract', 35(1).

Sudarmi, O. I. (2015) 'Program Kependudukan Keluarga Berencana Dan Pembangunan Keluarga ( Kkbpk )', (52).

Sukabumi, S. G. (2009) '3) 1,2,3)', (2004), pp. $1-6$.

Susantoputro, S. H. et al. (2014) 'Media Kedokteran Hewan Vol. 30, No. 1, Januari 2014', Potensi Suplementasi Potasium Klorida dan Sodium Bikarbonat Sebagai Thermotolerance Agent pada Hepar Broiler yang Terpapar Heat Stress Kronis The Potency of Potassium Chloride and Sodium Bicarbonate Suplementation as Thermotolerance Agent on Liver of Chro, 30(1), pp. 67-74.

Woodruff, T. K. and Shea, L. D. (2011) 'A new hypothesis regarding ovarian follicle development: Ovarian rigidity as a regulator of selection and health', Journal of Assisted Reproduction and Genetics, 28(1), pp. 3-6. doi: 10.1007/s10815-010- 
9478-4.

Zade, V. and Dabhadkar, D. (2015) 'Antifertility Effect of Alcoholic Extract of Moringa oleifera Stem Bark on Estrous Cycle and Estrogenic Activity of Female Albino Rat', American Journal of Advanced Drug Delivery, 3(3), pp. 223-235. 